\title{
IMPACT OF GAS ADSORPTION AND pH OF SOLUTIONS ON RADIATIVE LIFETIME OF MODIFIED POROUS SILICON LAYERS
}

\author{
A. I. Benilov ${ }^{1,3}$, I. V. Gavrilchenko ${ }^{1}$, I. V. Benilova ${ }^{2}$, \\ V. A. Skryshevsky ${ }^{1}$, M. Cabrera ${ }^{3}$ \\ ${ }^{1}$ Radiophysics Department, Kyiv National Taras Shevchenko University, 64, Volodymyrska, 01033, Kyiv, \\ Ukraine, e-mail: arthur@univ.kiev.ua \\ ${ }^{2}$ Institute of Molecular Biology and Genetics NAS of Ukraine, 150, Zabolotnogo, 03143, Kyiv, Ukraine \\ ${ }^{3}$ Laboratoire d'Electronique, Optoélectronique et Microsystèmes, Ecole Centrale de Lyon, \\ BP 163-69131, Ecully Cedex, France
}

\section{Abstract \\ IMPACT OF GAS ADSORPTION AND pH OF SOLUTIONS ON RADIATIVE LIFETIME OF MODIFIED POROUS SILICON LAYERS}

\section{A. I. Benilov, I. V. Gavrilchenko, I. V. Benilova, V. A. Skryshevsky, M. Cabrera}

The time-resolved photoluminescence and radiative decay time of modified layers of porous silicon (PS) were studied at the adsorption of saturated organic vapors and buffers solutions with different $\mathrm{pH}$. As-prepared PS samples were compared with ones after oxidation and deposition of poly (3,4-ethylenedioxythiophene) film. New type transducer for $\mathrm{pH}$ meter based on radiative decay time measurement of modified PS layers is proposed. The 1.9 times reduction of radiative lifetime of Sband is observed at the increasing of $\mathrm{pH}$ value from 2 to 9 .

Key words: porous silicon, photoluminescence, adsorption, buffers solutions.

\section{Анотація \\ ВПЛИВ АДСОРБЦІЇ ГАЗІВ ТА рН РОЗЧИНІВ НА ВИПРОМІНЮВАЛЬНИЙ ЧАС ЖИТТЯ МОДИФІКОВАНИХ ШАРІВ ПОРУВАТОГО КРЕМНІЮ}

\section{А. І. Бенілов, І. В. Гаврильченко, І. В. Бенілова, В. А. Скришевський, М. Кабрера}

Було досліджено кінетику фотолюмінесценції та час життя випромінювальної рекомбінації модифікованих шарів поруватого кремнію в умовах адсорбції насичених органічних парів та буферних розчинів з різними значеннями $\mathrm{pH}$. Щойно виготовлені зразки поруватого кремнію було порівняно із зразками, шо було окислено та покрито шаром полі-3,4етилдиокситиофену. Запропоновано новий тип трансдюсера, що базується на вимірі випромінювального часу життя, що чутливий до рівня рН. Спостерігається зменшення у 1.9 разів випромінювального часу життя S-смуги при зміні рН з 2 до 9.

Ключові слова: поруватий кремній, фотолюмінесценція, адсорбція, буферні розчини. 


\title{
Аннотация \\ ВЛИЯНИЕ АДСОРБЦИИ ГАЗОВ И рН РАСТВОРОВ НА ИЗЛУЧАТЕЛЬНОЕ ВРЕМЯ ЖИЗНИ МОДИФИЦИРОВАННЫХ СЛОЕВ ПОРИСТОГО КРЕМНИЯ
}

\author{
А. И. Бенилов, И. В. Гаврильченко, И. В. Бенилова, В. А. Скрышевский, М. Кабрера.
}

Были изучены кинетика фотолюминесценции и время жизни излучательной рекомбинации модифицированных слоев пористого кремния в условиях адсорбции насыщенных органических паров и буферных растворов с различным значением $\mathrm{pH}$. Свежеприготовленные образцы пористого кремния сравнивались с образцами, подвергшимися окислению и покрытыми слоем поли-3,4-этилдиокситиофена. Предложен новый тип трансдюсера, основанного на измерении излучательного времени жизни, чувствительного к уровню $\mathrm{pH}$. Наблюдается уменьшение в 1.9 раз излучательного времени жизни S-полосы при изменении рН с 2 до 9.

Ключевые слова: пористый кремний, фотолюминесценция, адсорбция, буферные растворы.

\section{Introduction}

Last 15 years photoluminescence (PL) in porous silicon (PS) has been devoted much attention. Recently, much effort has been directed to clarify the mechanism of visible radiative recombination yield that can achieve 5 and more percents at room temperature, and seems to give a new positive pulse for sustainable development of silicon optoelectronics. The first interpretation of this phenomenon was based on quantum confinement in Si nanoparticles that results in a bandgap up shift and arising of a strong visible PL at room temperature. Another important interest to visible PL in PS is related with development of chemical and biochemical sensors that use luminescent transducer. Chemical sensors based on PS display some advantages comparing with other transducers. Thus, it is observed the reversible quenching of PL intensity in presence of different gases, the quenching growths with partial pressure and dipole moment of adsorbed molecules [1]. PL intensity of PS drops by three orders of magnitude when PS is immersed in organic solvent of dielectric constant varying from 2 to 20 [2]. However, varying PS samples preparation, conditions of PL measurement the contradictory effects (increasing of PL intensity in gas atmosphere, independent of PL intensity versus dielectric constant, etc) are observed too $[1,3,4]$. The detail knowledge about kinetic of radiative recombination can give an important new insight in the interpretation of PL lifetime and assists to elaborate high sensitive and reversible chemical sensors.

In this work the PS time-resolved PL and PL decay time were studied in the atmosphere of different saturated organic vapors and the immersion to liquid solutions with $\mathrm{pH}$ varying from 2 to 9 .

\section{Samples and principles of pl decay time measurement}

PS samples were prepared using routine anodization process by applying of a constant anodic current to p- doped silicon slabs $(10 \Omega \cdot \mathrm{cm})$ with (100) crystallographic orientation. The etching had been carried out in a solvent of HF (48\%): Ethanol $=1: 1$ (vol.). The porosity of prepared samples is approximately $60 \%$, the porous layer thickness is about $1 \mu \mathrm{m}$. Samples were washed by distillated water and dried under nitrogen stream. Some samples were further exposed to open air for natural oxidation and improvement of red-band PL yield.

More deep oxidation was implemented to provide a better PS protection in aggressive environment (especially, for solutions with high $\mathrm{pH}$ values). Also a conductive poly (3,4-ethylenedioxythiophene) film (PEDOT) was deposited by routine spin-coating technique.

Time-resolved (PL) spectra have been measured in different environments such as saturated organic vapors and buffer solutions with different $\mathrm{pH}$. We used the multi-component "polymix" buffer with following composition: $2.5 \mathrm{mM}$ Tris, $2.5 \mathrm{mM}$ citric acid, $2.5 \mathrm{mM}$ sodium tetraborate, $2.5 \mathrm{mM}$ potassium phosphate, $\mathrm{pH}$ was adjusted with $1 \mathrm{M} \mathrm{HCl}$ or 1 $\mathrm{M} \mathrm{NaOH}$ solutions in order to obtain the expected $\mathrm{pH}$ value. Its buffer capacity is stable over a wide range of $\mathrm{pH}(5-9)$. This buffer is used for studying of $\mathrm{pH}$ influence on the ISFET responses, (especially enzyme-modified ISFETs) [5]. In range of $\mathrm{pH}$ 
(2.2-3.6) we applied acidic 0.1M buffer composed of Glycine and $\mathrm{HCl}$. PH was adjusted of $1 \mathrm{M} \mathrm{HCl}$.

PL spectra were studied at a room temperature by excitation the samples with a pulse of nitrogen laser $\lambda=337.1 \mathrm{~nm}, \mathrm{FWHM}=8 \mathrm{~ns}$, power in pulse is $20 \mathrm{~kW}$. The light spot was focused on the samples surface with diameter of $1 \mathrm{~mm}$ approximately. The proper band of emission was selected by a monochromator (MS2004, SOLAR T II) and registered by a combination of photomultiplier (HAMAMATSU C6270) and analog-to-digital board (up to $1 \mathrm{GHz}$ sample rate). The signal was processed and analyzed by PC.

The time correlated single photon counting technique (TCSPC) is applied for time-resolved PL spectra and decay time measurements [6]. The method uses an idea that luminescence intensity at a given time is proportional to the probability of a photon occurring at this time. Thus in TCSPC technique we wait for a single photon coming from the luminescent sample and measure a time at witch this photon was captured. Continuing such measurements we'll get a set of time intervals passed between excitation pulse and photon capturing. Having enough of these time intervals one can build a photon appearing probability distribution and in such way obtain a luminescence transient signal. TCSPC displays an excellent sensibility and signal acquisition precision but takes too much time to gain a necessary statistics (from tens minutes till hours) for signal reconstructing.

In our work we use a slightly different method to obtain PS luminescence transient signal: multiple photon counting or multichannel scaler (MS). MS operates within fixed time windows (from several ns to $\mu \mathrm{s})$ at witch several photon pulses can come from photon counter tube. This method is less time-precise as TCSPC but saves a lot of time and computer memory while data acquisition. A sequence of repetitive after excitation signals can be accumulated over many signal periods. This allows obtaining of transient waveform of desired precision but with a fixed time step corresponding to the data fetching time window. It uses a fixed time window of $200 \mathrm{~ns}$ to fetch the data from the counter and a memory array to keep 1000 counts. This allows monitoring up to $200 \mu$ s of signal decay (200ns time window steps per 1000 steps). As an excitation source a simple blue LED (405nm emission) was used. Hamamatsu H7360-03 photon counter is assembled with bandpass filter and objective lens (fig. 1).

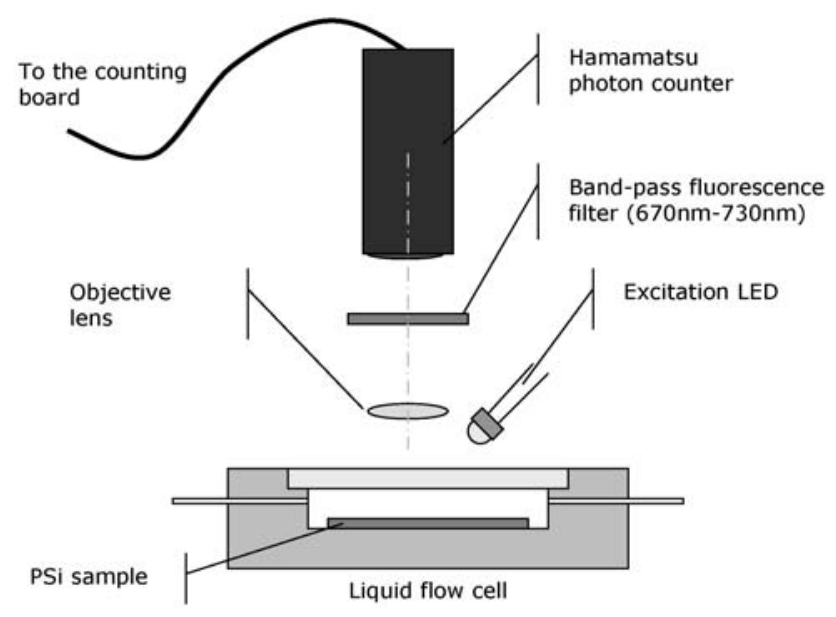

Fig. 1. Setup for PL decay time measurement.

\section{Results and discussion}

\subsection{Influence of dipole moment of organic vapors on PL decay time}

All measured samples manifest complex PL spectra which can be fitted, by at least, two intensive spectral bands centered at the $585 \mathrm{~nm}$ and $655 \mathrm{~nm}$, approximately (fig.2). Besides quantum yield they are distinguished different decay time. Red-shifted band displays slower PL decay time comparing with other one. This PS emission is named S- band and is related to the exciton radiative recombination in quantum confinement [7]. The large spectral width comes from inhomogeneous broadening and vibronic coupling of the radiative transitions. Sample aging at room ambient conditions results in surface oxidation that leads to blue shift of S- band and the increasing of PL intensity.

PL intensity and decay time both for $585 \mathrm{~nm}$ and $655 \mathrm{~nm}$ bands change while samples are being exposed in different organic vapors (fig. 3). However, only at long time decay time the PL decreases accordingly to exponential law.

It was established before that PL intensity can be quenched reversibly at the molecule adsorption via different mechanisms: i) the increase of the non-radiative recombination rate in the nanoparticles due to the alteration of polarizability of Si surface, ii) the change of the nanoparticle electronic structure; iii) the capture increase on the non-radiative traps at the forming of the straininduced defects when molecules are adsorbed; iv) increasing of electron-phonon interaction with 
surface vibronic modes of PS [1]. The adsorbed molecules with larger dipole moment stronger polarize the semiconductor surface, improves the capture of charge carriers on energetic levels of traps and rate of Schokley-Read-Hall recombination via those deep levels increases that leads to stronger PL quenching.

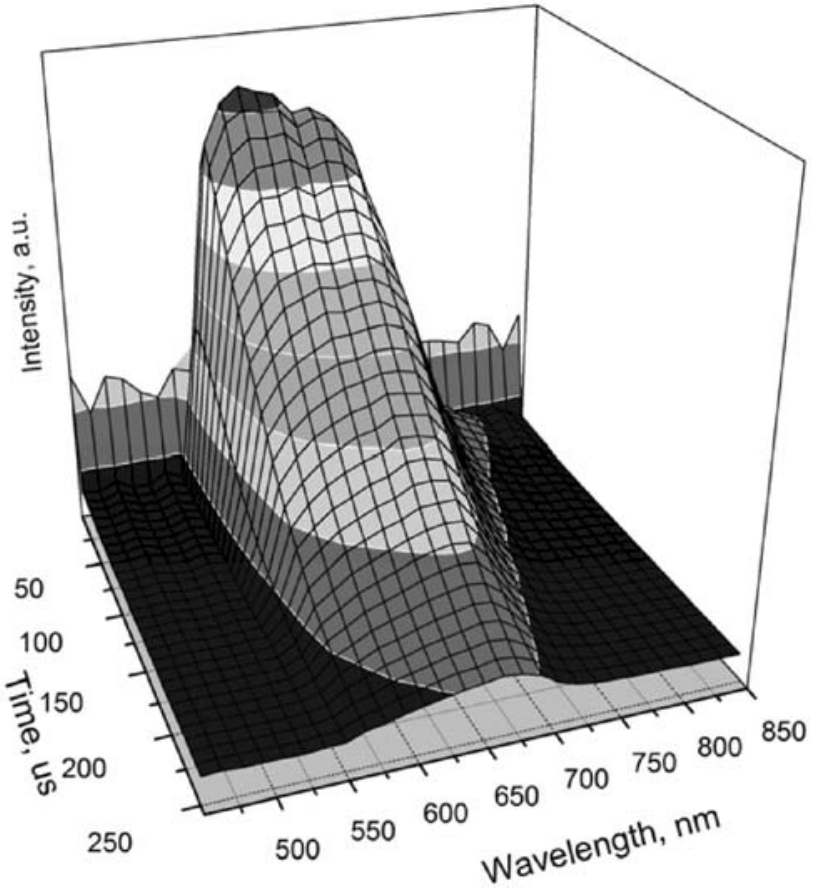

Fig. 2. Transient PL spectra for PS aged in air at $293 \mathrm{~K}$.

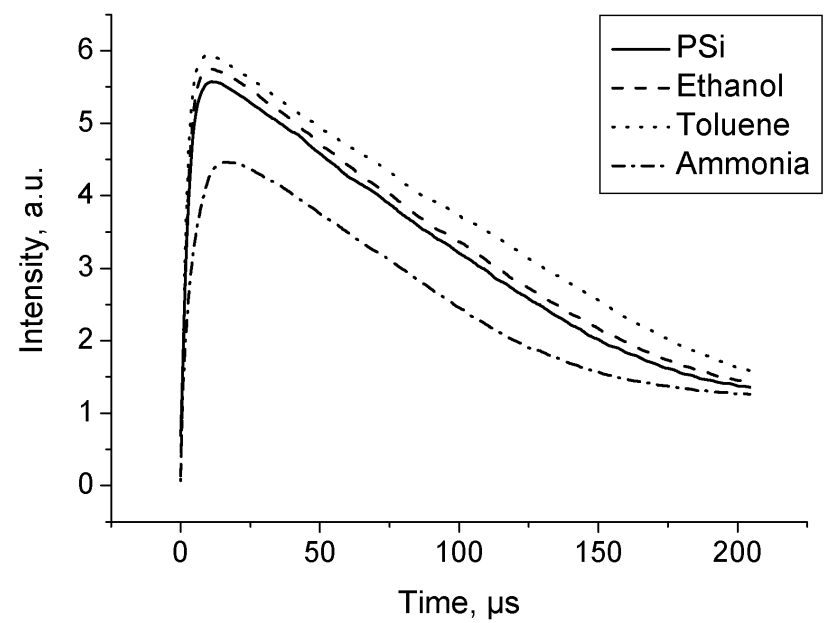

Fig. 3. PL decay time in different atmospheres of saturated vapors for PS aged in air at $293 \mathrm{~K}$

The radiative recombination rate $W_{R}$ is essentially an intrinsic property of the crystalline [2], whereas nonradiative recombination rate $W_{N}$ depends on the environment. The radiative quantum efficiency is: $\eta=W_{R} /\left(W_{R}+W_{N}\right)$, where
$W \sim 1 / \tau$. Owing to small quantum PL efficiency of PS (less than 5\%) it can be written that $W_{R}<<W_{N}$, $\eta \approx W_{R} / W_{N}=\tau_{N} / \tau_{R}$. Therefore, PL intensity should increase proportionally to the time of nonradiative recombination and inversely proportionally to radiative recombination time.

As it can be seen from fig.3, the PL decay time in saturated vapor of ammonium ( $9 \mu \mathrm{s}$, dipole moment of ammonium is $\mu=1.47$ Debyes) is much less then in air $(17 \mu \mathrm{s})$, in ethanol $(19 \mu \mathrm{s}, \mu=1.68 \mathrm{De}-$ byes) and toluene ( $45 \mu \mathrm{s}, \mu=0.375$ Debyes). Then, in contradictory to literature fact, that PL intensity decreases at adsorption of molecules with bigger dipole moment [1], the observed long time PL decay time is not correlated with dipole moment of adsorbed molecules.

Among reasons of such PL lifetime behavior we can note the following. The difference in molecule sizes and surface reactivity of PS film leads to different transparency of PS for different kinds of molecules that penetrate inside to pores. It means the condition of "saturation" does not achieve obligatory for all kinds of adsorbed molecules during the adsorption-desorption processes and above mentioned results are related to different partial pressures for tested gases. Since the PL intensity as well as lifetime depends on partial pressure the correlation between PL intensity (lifetime) and dipole moment is not manifested. Besides, there is the possibility of change of radiative recombination rate $\mathrm{W}_{\mathrm{R}}$ at adsorption of polar molecules that is discussed in [2].

Another effect is related to the alteration of adsorbed molecules polarizability as compared with gas of these molecules [8]. The molecular polarizability /ability of electronic system of a molecule to be distorted by an electric field/ may be divided into atomic and bond contributions. The bond dipole of the polarizable bond $\mathrm{i}$ is: $\mu_{i}=\mu_{i}^{0}+\mu_{i}^{i}$, where $\mu_{i}$ is the total dipole moment of the bond $i, \mu_{i}^{0}$ is the "permanent" dipole moment of the bond $i$, and $\mu_{i}^{i}$ is the induced dipole moment of the bond $i$. The induced dipole moment is given by $\mu_{i}^{i}=-\alpha_{i} E_{i}=-\alpha_{i} \sum_{j=1, i=1}^{n} T_{i j} \mu_{i}$, where $\alpha_{i}$ is the bond polarizability tensor, $E_{i}$ is the total electric field acting on the bond $i$ and $T_{i j}$ is the dipole field tensor. Accounting of bond polarization effects leads to change of dipole moment, i.e. for ethanol from 1.68 to 1.61 Debyes, ammonium from 1.472 to 1.334 Debyes, toluene from 0.375 to 0.421 Debyes, etc. [8]. 


\subsection{Influence of $p H$ solution on PL decay time}

Fig. 4 shows the PL decay time versus $\mathrm{pH}$ of buffer solution. Low pH value environment (acids) leads to $\mathrm{H}^{+}$protons adsorption on the PS surface, when the higher $\mathrm{pH}$ value (bases) results in $\mathrm{OH}^{-}$ hydroxide groups' adsorption [9]. Remembering, that $\mathrm{pH}$ scale is logarithmic and that each next value contains ten times less hydrogen ions we can conclude that PL decay time measurement is sensitive to change of $\mathrm{H}^{+}$ions concentration in range of more than 7 orders. The increasing of $\mathrm{pH}$ from 2 to 9 results in the decreasing of $\tau$ from 37 to $22 \mu \mathrm{s}$.
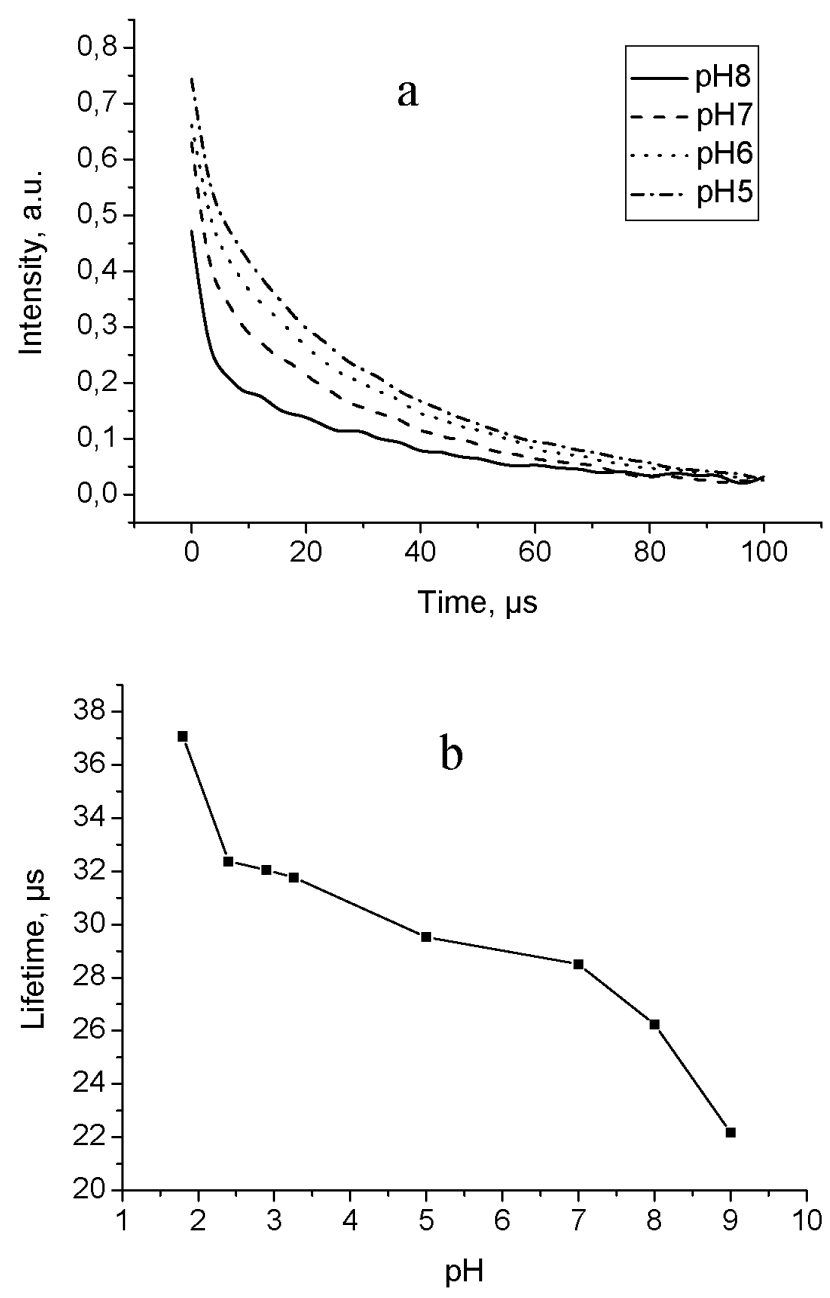

Fig. 4. PL decays of PS in several $\mathrm{pH}$ buffers $(20000$ integration cycles) (a) and PL decays time versus $\mathrm{pH}$ (b).

There is the correlation between $\tau$ and quantum efficiency of PS emission behaviors (fig.5). However, long time keeping in solution with high $\mathrm{pH}$ provokes a luminescence intensity quenching which is related to gradual PS layer degradation. As the same time, neither high $\mathrm{pH}$ solutions nor low $\mathrm{pH}$ solutions do not provoke any noticeable degradation of PL lumi- nescence decay time. The supplementary coating of PS surface by PEDOT or supplementary oxidation prevents against this degradation. The oxidized and covered by PEDOT samples display better sensitivity and stability to $\mathrm{pH}$ change. The possible explanation of sensitivity increasing is the swelling of the polymer insides the pores [10], increasing capillary condensation effects or passivation effects [11,12].
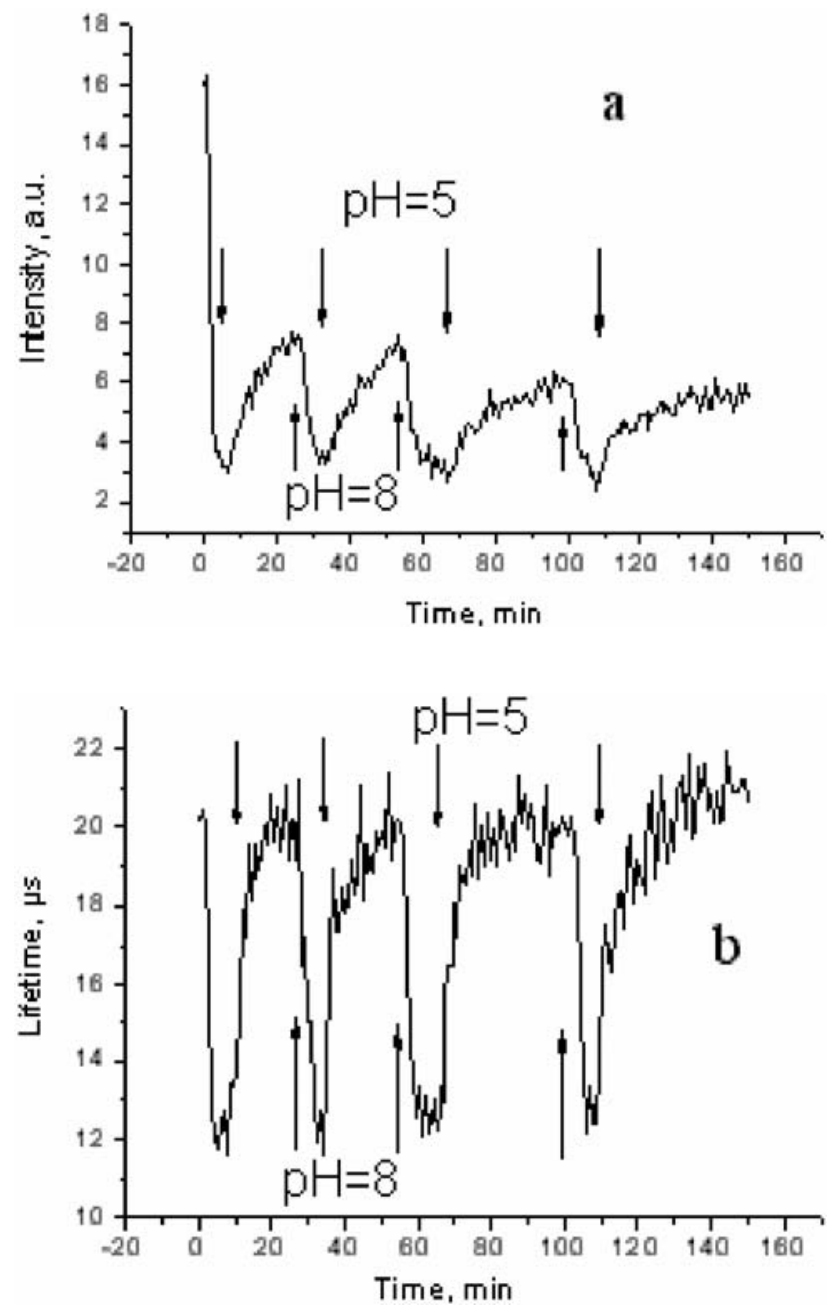

Fig. 5. PL intensity (a) and PL decay time (b) for PS covered by PEDOT at successive immersion to buffer solutions. Arrows show the moment of $\mathrm{pH}$ solution changing.

\section{Conclusions}

The measurement of PL decay time of S-band in PS layers is useful transducer for sensor applications. For example, it can be used as $\mathrm{pH}$ meter in range of $\mathrm{pH}$ change from 2 to 9 for biosensors. The observed PS degradation at the immersion into high $\mathrm{pH}$ solution can be resolved by supplementary oxidation or polymer deposition on PS surface. 


\section{Acknowledgements}

This project has been funded in part by Science \& Technology Center in Ukraine under contract STCU N3819, A.I.B. thanks CROUS (Fellowship from the French government) for funding this research; V.A.S. acknowledges the financial support of NATO Program Security Through Science (Grant CPB.NUKR.EV98167).

\section{Bibliography}

1. Properties of Porous Silicon, ed L. Canham, Emis, N18, INSPEC, UK. - 1997.

2. S. Fellah, F. Ozanam, N. Gabouze, J. - N. Chazalviel // Phys.Stat.Sol. (a) - 2000. - 182. - P. 367.

3. H. A. Lopez, X. L. Chen, S. A. Jenekne, P. M. Fauchet // J.Lum. - 1999. - 80. - P. 115.

4. V.A.Skryshevsky // Appl.Surf.Sci. - 2000. - 157. P. 145-150.
5. A. P. Soldatkin, A. V. El'skaya, A. A. Shul'ga, L. I. Netchiporouk, A. M. Nyamsi Hendji, N. Jaffrezic-Renault, C. Martelet // Anal Chim Acta. 1993. - 283. - P. 695.

6. B. Valeur, Molecular Fluorescence // Wiley-VCH, Weinheim. -2002.

7. O. Bisi, S. Ossicini, L. Pavesi // Surface Sci.Reports, -2000 . - 38. - P. 1-126.

8. B. Ma, J. - H. Lii, N. L.Allinger // J.Computational Chemistry. -2000 . - 21. - P. 813.

9. S. M. Sze, Semiconductor Sensors // John Wiley \&Sons, Inc, N.Y. - 1994.

10. J. W. Bakker, H. Arwin, G. Wang, K.Jarrendahl // Phys.Stat.Sol. (a) - 2003. - 197. - P. 378.

11. V.A.Skryshevsky, V.M.Zinchuk, A.I.Benilov, Yu.S.Milovanov, O.V.Tretyak // Semicond. Sci. Technol. - 2006. - 21. P.1605.

12. O.V. Tretyak, V.A.Skryshevsky, V.A.Vikulov, Yu.V.Boiko, V.M.Zinchuk // Thin Solid Films 2003. - 445. P. 144. 